\title{
Pengaruh Sales Growth, Debt To Equity Ratio, Total Assets Turnover terhadap Return On Assets pada Perusahaan Property dan Real Estate yang Terdaftar di Bursa Efek Indonesia 2018-2020
}

\author{
Dian Ramli ${ }^{1}$, Yusnaini ${ }^{2}$ \\ STMB MULTISMART \\ rajalidian@gmail.com, yusniani1010@gmail.com,
}

\begin{abstract}
*Penulis Korespondensi
Diajukan : 1 Januari 2022

Disetujui : 8 Januari 2022

Dipublikasi : : 10 Januari 2022
\end{abstract}

\begin{abstract}
The purpose of this study was to determine the effect of Sales Growth, Debt to Equity Ratio, Total Assets Turnover to Return on Assets property and real estate sector companies that are listed in Indonesia Stock Exchange. The population in this study are supporting property and real estate sub-sector companies listed on Indonesia Stock Exchange from 2018-2020. By using a sampling technique (purposive sampling) gained 49 (forty-nine) companies that will serve as the object of research. The testing method used to see the effect of independent variables on the dependent variable is the data panel regression analyze method. Based on this research simultaneously the effectiveness of Sales Growth not significantly to Return on Asset but Debt to Equity Ratio, Total Assets Turnover on Return on Assets significantly influence Return on Assets. Partial test shows that the effectiveness of Sales Growth has a positive effect but not significant Return on Assets. Debt to Equity Ratio has a negative and significant on Return on Assets. Total Assets Turnover has a positive and significant.
\end{abstract}

Keywords: Sales Growth, Debt to Equity Ratio, Total Assets Turnover, Return on Assets

\section{PENDAHULUAN}

Kemampuan suatu perusahaan dapat dinilai dengan menggunakan laporan keuangan yang diterbitkan perusahaan. Tercapainya tujuan perusahaan dalam menghasilkan laba pada laporan keuangan yang diterbitkan perusahaan dapat digunakan sebagai acuan dalam pengambilan keputusan baik pemilik perusahaan maupun investor.

Laba merupakan salah satu acuan investor dalam berinvestasi, dimana dalam hal ini rasio yang digunakan untuk menilai kemampuan perusahaan dalam menghasilkan laba yaitu rasio profitabilitas. Profitabilitas dapat digunakan sebagai acuan tentang keeksistensian perusahaan dapat berdiri di masa depan. Menurut (Harahap, 2015) Profitabilitas menggambarkan kemampuan perusahaan dalam mendapatkan laba melalui semua kemampuan, dan sumber daya yang ada seperti kegiatan penjualan, kas, modal, jumlah karyawan, jumlah cabang dan sebagainya yang menghasilkan profit atau laba. Profitabilitas suatu perusahaan memberikan sumbangsih yang besar terhadap pada perekonomian Indonesia dalam hal pertumbuhan dan pembangunan ekonomi karena berkaitan dengan pendapatan nasional.

Kenaikan sektor property juga mendukung pertumbuhan perekonomian Indonesia misalnya dari kenaikan harga property dari tahun ke tahun serta daya beli masyarakat dalam memiliki hunian. Pembangunan suatu property dalam penyerapan tenaga kerja juga akan berpengaruh secara langsung bagi perkembangan perekonomian Indonesia dalam hal meningkatkan daya beli masyarakat. Selain itu, sektor property dan real estate memiliki cakupan yang luas dengan kehidupan manusia misalnya perumahan, apartemen, gedung perkantoran, hotel, pusat 
perbelanjaan (mall) yang mendukung aktivitas manusia sehari-hari. Kenaikan jumlah penduduk juga mengakibatkan banyaknya pembangunan secara besar-besaran dalam menunjang kebutuhan manusia. Pembangunan dari sektor property dan real estate akan berpengaruh terhadap penyerapan tenaga kerja yang menjadi salah satu faktor penunjang pembangunan ekonomi dan berpengaruh pada meningkatkan daya beli masyarakat yang akan memiliki pengaruh pada sektor ekonomi lainnya.

Berdasarkan data Biro Pusat Statistik (BPS) pertambahan jumlah penduduk Indonesia tahun 2010-2020 BPS mencatatkan jumlah penduduk Indonesia saat ini sebesar 270,2 juta jiwa sedangkan tahun 2010 jumlah penduduk Indonesia tercatat sebanyak 237,63 juta jiwa. Adanya kenaikan sebesar 32,56 juta jiwa. Sehingga dalam hal ini, pertumbuhan penduduk berdampak pada tingginya tingkat pembangunan yang dalam hal ini memberikan dampak yang positif bagi perusahaan sektor property dan real estate.

Rasio profitabilitas yang digunakan dalam penelitian ini menggunakan Return On Assets (ROA). ROA merupakan kemampuan suatu perusahaan dalam menghasilkan laba berdasarkan jumlah aktiva yang dimilikinya. Apabila nilai dari ROA semakin besar, maka hal tersebut menunjukkan kinerja perusahaan yang semakin baik. Kondisi ini akan mempengaruhi tingkat keuntungan yang diperoleh suatu perusahaan. Penurunan Return On Assets menunjukkan adanya penurunan laba bersih yang diperoleh suatu perusahaan ataupun disebabkan oleh penjualan aset yang dimiliki perusahaan. perusahaan. Berikut merupakan rata-rata tingkat pertumbuhan ROA pada Sektor perusahaan property dan real estate yang terdaftar di BEI selama periode 2018-2020.

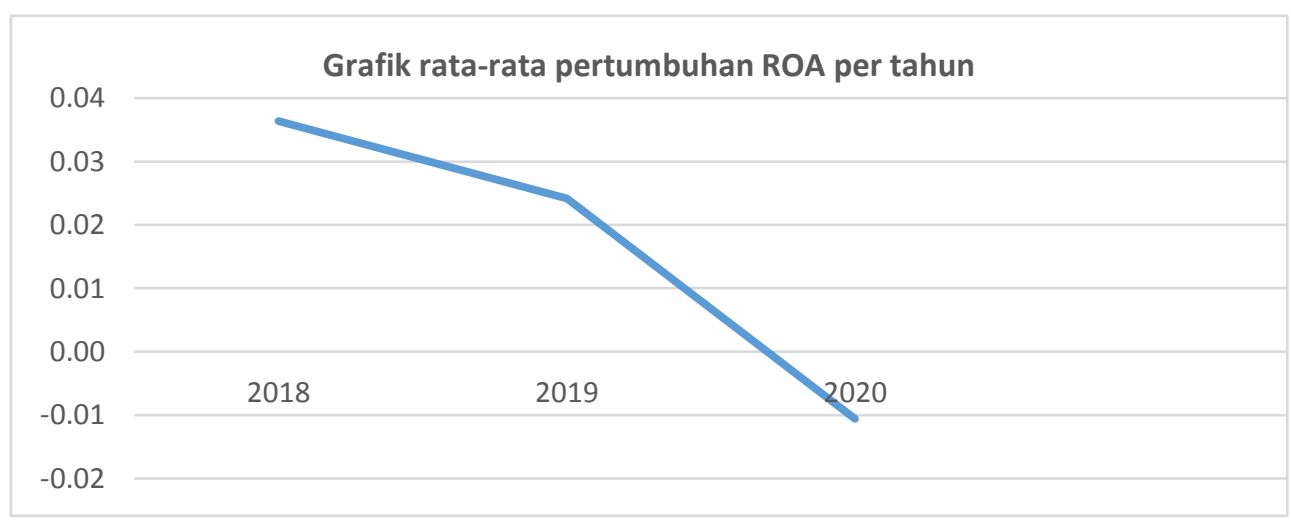

Gambar 1. Grafik Pertumbuhan ROA Beberapa Perusahaan property dan real estate

Sumber: www.idx.co.id (Data diolah oleh peneliti,2021)

Gambar 1. menunjukkan rata-rata pertumbuhan profitabilitas Return On Assets (ROA) pada perusahaan property dan real estate yang terdaftar di Bursa Efek Indonesia tahun 2018-2020 yang mengalami penurunan yang cukup signifikan dari periode 2018 sampai dengan periode 2020 . Tahun 2020, ROA rata-rata perusahaan mencapai minus 0,01 . Namun selain itu, terdapat beberapa perusahaan yang mengalami tingkat pertumbuhan ROA yang mengalami pertumbuhan laba yang fluktuasi selama periode 2018-2020, dimana pada tahun 2020 memiliki pertumbuhan laba minus. 


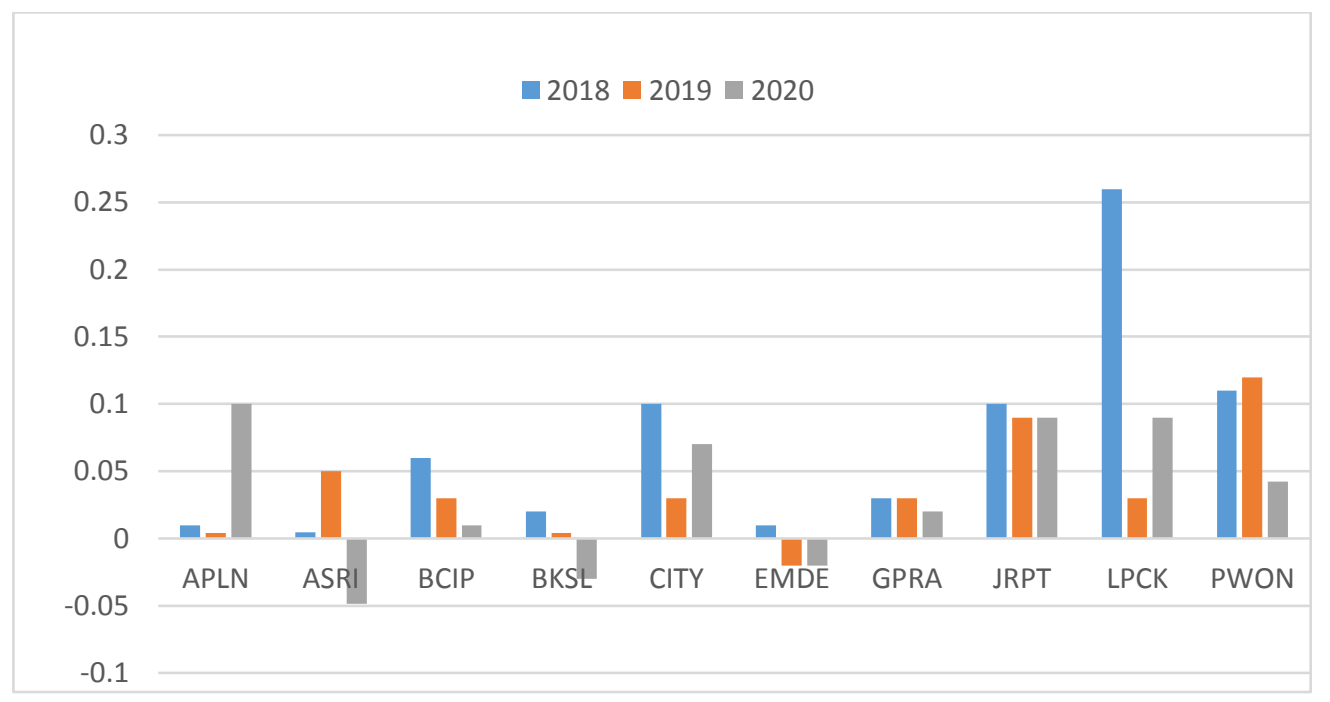

Gambar 2. Grafik Pertumbuhan ROA Beberapa Perusahaan property dan real estate Periode 2018-2020.

Sumber: www.idx.co.id (Data diolah oleh peneliti,2021)

Pada perusahaan yang mengalami nilai profitabilitas (ROA) yang baik yaitu Lippo Cikarang Tbk (LPCK) dengan tingkat profitabilitas (ROA) mencapai 26\% pada tahun 2018 sedangkan yang terendah adalah Sentul Bekasi City Tbk (BKSL) yang mengalami profitabilitas terendah sebesar $3 \%$ pada tahun 2020. Pada perhitungan akumulasi tahun untuk pertumbuhan nilai profitabilitas ROA pada tahun 2018 sebesar 7\% dan terendah pada tahun 2020 sebesar 3,3\%. Perusahaan dalam menarik investor melakukan investasi dituntut untuk menjaga nilai profitabilitasnya sehingga investor tertarik melakukan investasi hal ini bertujuan untuk menghimpun dana atau memperoleh dana dari masyarakat untuk mengembangkan usaha perusahaan sehingga dapat meningkatkan laba yang diperoleh perusahaan.

\section{Penelitian Terdahulu}

\section{STUDI LITERATUR}

Penelitian ini juga didasari dengan penelitian- penelitian sebelumnya mengenai pengaruh rasio keuangan terhadap ROA. Hasil-hasil penelitian sebelumnya menunjukkan adanya perbedaan dari hasil yang diperoleh, seperti penelitian yang dilakukan oleh (Arifin, Sarita, Montundu, \& Madi, 2019) pada pertumbuhan penjualan adanya pengaruh yang positif dan signifikan terhadap Return On Assets sedangkan pada penelitian (Sari \& Aulia, 2021) menunjukkan pertumbuhan penjualan berpengaruh negatif dan signifikan terhadap Return On Assets pada perusahaan PT. Ultrajaya Milk Industri co. tbk tetapi pada hasil penelitian yang dilakukan (Wulandari \& Gultom, 2018), yang menunjukkan hasil pertumbuhan penjualan tidak berpengaruh terhadap Return On Assets pada perusahaan industri barang makanan dan minuman yang terdaftar di Bursa Efek Indonesia tahun 2014-2017.Penelitian Debt to Equity Ratio terhadap Return On Assets hasilnya berpengaruh positif dan signifikan yang dilakukan oleh (Setiawan \& Cahyono, 2019) pada Return On Assets. Hasil yang berbeda pada penelitian yang dilakukan oleh (Jenni, et al., 2019) berpengaruh negatif dan signifikan sedangkan pada penelitian yang dilakukan oleh (Fadilah, Ghani , \& Amaniyah , 2017) berdasarkan uji parsial tidak memiliki pengaruh signifikan terhadap rentabilitas (ROA). Penelitian yang dilakukan (Tyas, 2018) bahwa secara parsial Total Assets Turnover berpengaruh positif dan signifikan terhadap Return On Assets, namun pada penelitian (Sanjaya, Sudirman, \& Dewi, 2015) terdapat hasil tidak berpengaruh signifikan terhadap profitabilitas. 


\section{Return On Assets}

Return On Assets, merupakan salah satu rasio profitabilitas yang artinya mengukur kemampuan suatu perusahaan dalam menghasilkan laba dari usaha yang dijalankan oleh pemilik perusahaan. Menurut (Hantono, 2018) Return On Investment atau Return On Assets adalah rasio yang menunjukkan tingkat pengembalian bisnis dari seluruh investasi yang telah dilakukan. Menurut (Sudana, 2015)) Return On Assets menunjukkan kemampuan perusahaan dengan menggunakan seluruh aktiva yang dimiliki untuk menghasilkan laba setelah pajak. Rasio ini penting bagi pihak manajemen untuk mengevaluasi efektivitas dan efisiensi manajemen perusahaan dalam mengelola seluruh aktiva perusahaan. Semakin besar ROA, berarti semakin efisien penggunaan aktiva perusahaan atau dengan kata lain dengan jumlah aktiva yang sama bisa menghasilkan laba yang lebih besar dan sebaliknya. Return On Assets (ROA) yang memiliki arah hubungan positif menunjukkan bahwa dari total aktiva yang dipergunakan untuk beroperasi, perusahaan mampu memberikan laba bagi perusahaan sebaliknya apabila Return On Assets (ROA) yang arah hubungan negatif disebabkan laba perusahaan dalam kondisi negatif pula atau rugi, hal ini menunjukkan kemampuan dari modal yang diinvestasikan secara keseluruhan belum mampu menghasilkan laba.

Return On Assets $=\frac{\text { Earning After Tax }}{\text { Total Assets }}$

Sumber: (Sudana, 2015)

\section{Sales Growth}

Sales Growth diartikan sebagai pertumbuhan penjualan. Menurut (Wulandari \& Gultom, 2018) pertumbuhan penjualan merupakan kenaikan penjualan perusahaan dari waktu ke waktu. Perusahaan yang memiliki pertumbuhan penjualan positif akan meningkatkan probabilitas perusahaan tersebut karena adanya pertumbuhan penjualan maka akan meningkatkan laba perusahaan.

Dalam mencatatkan pertumbuhan penjualan yang setiap tahun mengalami peningkatan adanya faktor pendukung lainnya seperti kenaikan penjualan dari segi kualitas barang yang dihasilkan perusahaan serta kuantitas yang diperoleh konsumen. Pemilik perusahaan selalu menghadirkan inovasi ataupun terobosan baru agar produk yang dihasilkan dapat meningkatkan penjualan. Hal ini didukung hasil penelitian (Arifin, Sarita, Montundu, \& Madi, 2019) yang menyatakan pertumbuhan penjualan berpengaruh positif dan signifikan terhadap Return On Assets (ROA) dalam penelitian menyatakan pertumbuhan penjualan berpengaruh positif dan signifikan terhadap Return On Assets (ROA) pada perusahaan food and beverage yang terdaftar di Bursa Efek Indonesia.

Psales $=\frac{\text { Penjualan }_{t}-\text { Penjualan }_{t-1}}{\text { Penjualan }_{t-1}}$

Sumber: (Harahap, 2015)

\section{Debt to Equity Ratio}

Menurut (Hantono, 2018) Debt to Equity Ratio adalah rasio yang menunjukkan sejauh mana modal sendiri menjamin seluruh utang. Semakin tinggi DER menunjukkan komposisi total hutang (jangka pendek dan jangka panjang) semakin besar dibandingkan dengan total modal sendiri, sehingga berdampak semakin besar beban perusahaan terhadap kreditur.

Rasio ini juga dapat dibaca sebagai perbandingan antara dana pihak luar dengan dana pemilik perusahaan. Menurut (Fadilah, Ghani , \& Amaniyah , 2017) rasio ini menunjukkan komposisi atau struktur modal dari total pinjaman (hutang) terhadap total modal yang dimiliki perusahaan. Debt to Equity Ratio memiliki hubungan negatif yang artinya jumlah nilai DER mengalami penurunan tetapi laba yang dihasilkan perusahaan tidak mengalami kenaikan hal ini disebabkan banyaknya beban bunga yang dibebankan oleh kreditor dan harus dibayarkan oleh perusahaan sejalan dengan penelitian yang dilakukan oleh (Jenni, et al., 2019) menunjukkan pengaruh negatif dan signifikan. 
Owner: Riset \& Jurnal Akuntansi

e-ISSN : 2548-9224|p-ISSN : 2548-7507

Volume 6 Nomor 1, Januari 2022

Hasil penelitian ini juga sejalan dengan penelitian yang dilakukan oleh (Mahardhika \& Marbun,, 2016)menunjukkan hasil berpengaruh negatif dan signifikan.

Debt to Equity $=\frac{\text { Sales }}{\text { Total Assets }}$

Sumber: (Sudana, 2015)

Total Assets Turnover

Menurut (Sudana, 2015) mengukur efektivitas penggunaan seluruh aktiva dalam menghasilkan penjualan, dan semakin besar rasio ini berarti semakin efektif pengelolaan seluruh aktiva yang dimiliki perusahaan. Menurut (Hantono, 2018) Total Assets Turnover yang disebut asset turnover yaitu perputaran aktiva menunjukkan kemampuan manajemen mengelola seluruh investasi (aktiva) guna menghasilkan penjualan. Pada rasio ini dikenal sebagai rasio aktivitas yang menilai kaitan dalam penggunaan aset serta menilai berapa jumlah pengembalian yang dapat diterima perusahaan dari penggunaan aset tersebut. Total Assets Turnover menunjukkan arah positif semakin meningkatnya nilai dari Total Assets Turnover menunjukkan semakin efisiensi dalam penggunaan aset yang dimiliki perusahaan. Hal ini sejalan dengan penelitian yang dilakukan oleh (Tyas, 2018) berpengaruh positif dan signifikan serta Menurut (Arsyanti, Tripuspitorini, \& Djatnika, 2020) pada penelitiannya menunjukkan hasil yang sama yakni berpengaruh positif dan signifikan.

Total Assets Turnover $=\frac{\text { Total Utang }}{\text { Total Modal }}$

Sumber: (Hantono, 2018)

\section{Populasi dan Sampel}

METODE

Pada pengambilan populasi dan teknik pengambilan sampel menggunakan perusahaan property dan real estate yang terdaftar pada Bursa Efek Indonesia. Teknik pengambilan sampel menggunakan teknik purposive sampling dengan menggunakan kriteria seperti terlihat pada tabel berikut sebagai berikut.

Tabel 1. Kriteria Pemilihan Sampel

\begin{tabular}{|l|l|l|}
\hline No. & Kriteria Pemilihan Sampel & Jumlah \\
\hline 1. & $\begin{array}{l}\text { Perusahaan property dan real estate yang terdaftar di Bursa } \\
\text { Efek Indonesia 2018-2020 }\end{array}$ & 65 \\
\hline 2. & $\begin{array}{l}\text { Perusahaan property dan real estate yang tidak } \\
\text { mempublikasikan laporan keuangan di Bursa Efek Indonesia } \\
\text { pada tahun 2018-2020 }\end{array}$ & 147 \\
\hline & Jumlah Sampel (49x3) & $16)$ \\
\hline
\end{tabular}

Sumber tabel : www.idx.co.id (Data diolah oleh peneliti,2021)

Pada tabel 1, jumlah populasi pada penelitian sebanyak 65 perusahaan sesuai dengan periode penelitian yang dilakukan pada tahun 2018-2020 pada perusahaan property dan real estate yang terdaftar pada Bursa Efek Indonesia. Dengan menggunakan pemilihan kriteria, sampel yang dapat digunakan sebanyak 49 perusahaan property dan real estate yang terdaftar pada Bursa Efek Indonesia. 
Owner: Riset \& Jurnal Akuntansi

e-ISSN : 2548-9224|p-ISSN : 2548-7507

Volume 6 Nomor 1, Januari 2022

DOI : https://doi.org/10.33395/owner.v6i1.647

\section{Variabel Penelitian Operasional}

Tabel 2. Variabel Penelitian Operasional

\begin{tabular}{|c|c|c|}
\hline Variabel & Indikator & $\begin{array}{l}\text { Skala } \\
\text { Pengukuran }\end{array}$ \\
\hline $\begin{array}{l}\text { Sales } \text { Growth } \\
\text { (X1) }\end{array}$ & $\begin{array}{l}\text { Psales }=\frac{\text { Penjualan }_{t}-\text { Penjualan }_{t-1}}{\text { Penjualan }_{t-1}} \\
\text { (Harahap:2015) }\end{array}$ & Rasio \\
\hline $\begin{array}{l}\text { Debt to Equity } \\
\text { Ratio } \\
\text { (X2) }\end{array}$ & $\begin{array}{l}\text { Debt to Equity }=\frac{\text { Sales }}{\text { Total Assets }} \\
\text { Sudana }(2018: 25)\end{array}$ & Rasio \\
\hline $\begin{array}{l}\text { Total Assets } \\
\text { Turnover (X2) }\end{array}$ & $\begin{array}{l}\text { Total Assets Turnover }=\frac{\text { Total Utang }}{\text { Total Modal }} \\
\text { Hantono (2018:12) }\end{array}$ & Rasio \\
\hline $\begin{array}{l}\text { Return On Assets } \\
\text { (Y) }\end{array}$ & $\begin{array}{l}\text { Return on Asset }=\frac{\text { Earning After Tax }}{\text { Total Assets }} \\
\text { Sudana }(2015: 26)\end{array}$ & Rasio \\
\hline
\end{tabular}

\section{Jenis dan Sumber Data}

Sumber data yang digunakan adalah data sekunder yang merupakan laporan keuangan sektor property dan real estate yang terdaftar pada Bursa Efek Indonesia yang diambil pada tahun 20182020 yang dikutip dari situs www.idx.co.id

\section{Teknik Analisis Data}

Regresi Data Panel

Pengujian terhadap hipotesis dalam penelitian ini menggunakan metode analisis regresi data panel. Analisis regresi digunakan mengetahui bagaimana variabel dependen dapat diprediksi melalui variabel secara individual. Adapun persamaan regresi yang digunakan dalam penelitian adalah:

Yit $=\beta 0+\beta 1 \mathrm{X} 1 \mathrm{it}+\beta 2 \mathrm{X} 2 \mathrm{it}+\beta 3 \mathrm{X} 3 \mathrm{it}+$ eit

Keterangan:

Yit $\quad=$ ROA pada perusahaan property dan real estate yang terdaftar di Bursa Efek Indonesia tahun 2018-2020.

$\beta 0=$ Konstanta

$\beta 1-\beta 4=$ Koefisien regresi variabel $\mathrm{X} 1$

$\mathrm{X} 1$ it $\quad=$ Sales Growth pada perusahaan property dan real estate yang terdaftar di Bursa Efek Indonesia tahun 2018-2020.

X2it $=$ Total Assets Turnover pada perusahaan property dan real estate yang terdaftar di Bursa Efek Indonesia tahun 2018-2020.

X3it = Total Assets Turnover pada perusahaan property dan real estate yang terdaftar di Bursa Efek Indonesia tahun 2018-2020.

eit $\quad=$ Error Term pada perusahaan property dan real estate yang terdaftar di Bursa Efek Indonesia tahun 2018-2020. 


\section{Uji Statistik Deskriptif}

\section{HASIL}

Analisis deskriptif terhadap data sampel yang ada baik terhadap variabel dependen dan variabel independen yang dilihat dari nilai maksimum, nilai minimum, nilai rata-rata, dan nilai standar deviasi. Dalam penelitian ini, variabel yang diperhitungkan statistik deskriptif adalah Return on Assets, Sales Growth, Debt to Equity, serta Total Assets Turnover. Berdasarkan analisis statistik deskriptif diperoleh gambaran sebagai berikut:

Tabel 3. Statistik Deskriptif dari Return on Assets,

Sales Growth, Debt to Equity, dan Total Assets Turnover.

\begin{tabular}{|l|l|l|l|l|}
\hline & ROA & SG & DER & TATO \\
\hline Mean & 0.016664 & -0.278130 & 0.672320 & 0.132344 \\
\hline Median & 0.011699 & -0.095235 & 0.508266 & 0.130129 \\
\hline Maximum & 0.258529 & 0.889967 & 3.736219 & 0.389397 \\
\hline Minimum & -0.375159 & -4.334778 & -10.25555 & 0.001224 \\
\hline Std. Dev. & 0.062531 & 0.684486 & 1.157169 & 0.082208 \\
\hline Skewness & -1.219351 & -2.568140 & -5.275348 & 0.425634 \\
\hline Kurtosis & 14.55610 & 12.84793 & 55.96787 & 2.710330 \\
\hline & & & & \\
\hline Jarque-Bera & 854.3808 & 755.5990 & 17866.09 & 4.952463 \\
\hline Probability & 0.000000 & 0.000000 & 0.000000 & 0.084059 \\
\hline & & & & \\
\hline Sum & 2.449560 & -40.88513 & 98.83104 & 19.45456 \\
\hline Sum Sq. Dev. & 0.570885 & 68.40407 & 195.4999 & 0.986686 \\
\hline & & & & \\
\hline Observations & 147 & 147 & 147 & 147 \\
\hline
\end{tabular}

Sumber Tabel: Hasil Pengolahan Data Eviews9

Dari analisis deskriptif diketahui nilai Return on Assets (ROA) minimum adalah -0.375160 dan nilai ROA maksimum adalah 0.258530. Sementara rata-rata dan standar deviasi dari ROA adalah 0.016664 dan 0.062531 .

Perusahaan yang memiliki nilai ROA terendah adalah PT. Lippo Cikarang Tbk pada tahun 2020 yaitu sebesar -0.375160 sedangkan perusahaan dengan nilai ROA tertinggi adalah PT. Lippo Cikarang Tbk pada tahun 2018 sebesar 0.258530.

Pada jumlah nilai variabel SG diketahui nilai minimum adalah -4.33478 dan nilai variabel Sales Growth (SG) dengan nilai maksimum adalah 0.88997.Pada nilai rata-rata dan standar deviasi Sales Growth (SG) adalah -0.278130 dan 0.684486 Perusahaan yang memiliki nilai Sales Growth (SG) terendah PT. Trimitra Propertindo Tbk pada tahun 2020 sebesar -4.33478 sedangkan nilai Sales Growth (SG) tertinggi yaitu PT. Urban Jakarta Propertindo Tbk pada tahun 2018 sebesar 0.88997.

Diketahui jumlah nilai variabel Debt to Equity Ratio (DER) diketahui nilai minimum adalah 10.25555 dan nilai variabel Debt to Equity Ratio dengan nilai maksimum adalah 3.736220 Pada nilai rata-rata dan standar deviasi Debt to Equity Ratio adalah 0.672320 dan 1.157169 Perusahaan yang memiliki nilai Debt to Equity Ratio terendah adalah PT. Binakarya Jaya Abadi pada tahun 2020 sebesar -10.25555 sedangkan nilai Debt to Equity Ratio tertinggi yaitu PT. Pollux Properti Indonesia Tbk. pada tahun 2020 adalah sebesar 3.736220.

Data diatas menunjukkan nilai dari Total Assets Turnover (TATO) adalah nilai minimum sebesar 0.001220 pada nilai maksimum yaitu sebesar 0.389400 sementara nilai rata-rata dan standar deviasi adalah 0.132344 dan 0.082208 . Perusahaan yang memiliki nilai TATO terendah adalah PT. Eureka Prima Jakarta Tbk pada tahun 2020 sebesar 0.001220 dan nilai tertinggi oleh PT. Putradelta Lestari Tbk pada tahun 2020 sebesar 0.389400. 
Owner: Riset \& Jurnal Akuntansi

e-ISSN : 2548-9224|p-ISSN : 2548-7507

Volume 6 Nomor 1, Januari 2022

DOI : https://doi.org/10.33395/owner.v6i1.647

\section{Uji Asumsi Klasik}

\section{Uji normalitas}

Uji normalitas dalam penelitian ini tidak dilakukan karena data yang diteliti merupakan data panel dengan jumlah observasi data yang besar, yaitu $n=147$. Pada data panel dengan jumlah observasi data yang besar, uji normalitas data dapat diabaikan.

\section{Uji Multikolinearitas}

Tabel 4. Uji Multikolinearitas

\begin{tabular}{|l|l|l|l|}
\hline & SG & DER & TATO \\
\hline SG & 1.000000 & 0.185657 & 0.442340 \\
\hline DER & 0.185657 & 1.000000 & 0.155582 \\
\hline TATO & 0.442340 & 0.155582 & 1.000000 \\
\hline
\end{tabular}

Sumber Tabel: Pengolahan Data Eviews9

Berdasarkan Tabel 4, dari hasil pengujian disimpulkan bahwa tidak terdapat gejala multikolinearitas antar variabel independen. Hal ini korelasi antar variabel independen tidak lebih dari 0,8

\section{Uji Heterokedasitas}

Tabel 5. Uji Heterokedasitas

\begin{tabular}{|l|l|l|l|}
\hline Heteroskedasticity Test: White \\
\hline F-statistic & 0.496765 & Prob. F(9,137) & 0.8747 \\
\hline Obs*R-squared & 4.645625 & Prob. Chi-Square(9) & 0.8640 \\
\hline Scaled explained SS & 56.82622 & Prob. Chi-Square(9) & 0.0000 \\
\hline
\end{tabular}

Sumber Tabel: Pengolahan Data Eviews9

Berdasarkan Tabel 5, diperoleh hasil berupa nilai chi squares sebesar 0.8640. Nilai probabilitas chi squares lebih besar dari taraf signifikansi $(0.8640>0.05)$ artinya tidak menolak H0 atau heterokedasitas.

\section{Uji Autokolerasi}

Tabel 6. Uji Autokolerasi

\begin{tabular}{|l|l|l|l|}
\hline R-squared & 0.225756 & Mean dependent var & 0.014580 \\
\hline Adjusted R-squared & 0.209513 & S.D. dependent var & 0.059395 \\
\hline S.E. of regression & 0.052808 & Sum squared resid & 0.398779 \\
\hline F-statistic & 13.89874 & Durbin-Watson stat & 1.235860 \\
\hline Prob(F-statistic) & 0.000000 & & \\
\hline
\end{tabular}

Sumber Tabel: Pengolahan Data Eviews9

Berdasarkan Tabel 6,menunjukkan nilai dari statistik Durbin-Watson adalah 1.235860. Karena nilai statistik Durbin-Watson terletak di antara 1 dan 3, yakni $1<1.235860<3$, maka asumsi nonautokorelasi terpenuhi. Dengan kata lain, tidak terjadi gejala autokorelasi.

\section{Pemilihan Model Regresi Data Panel Uji Chow}

Tabel 7. Uji Chow

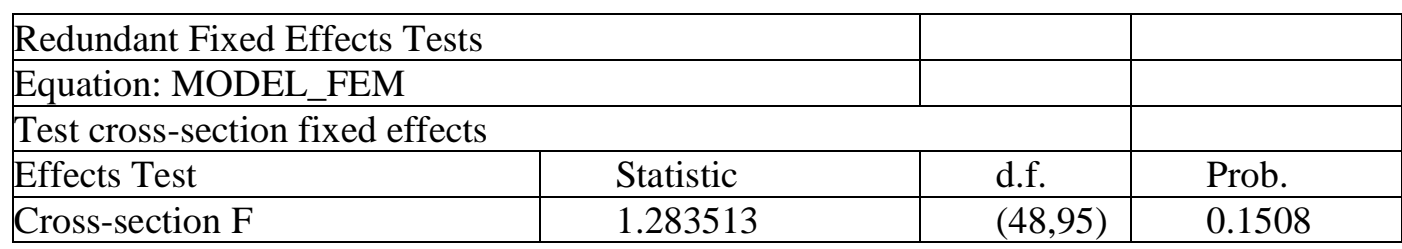


Owner: Riset \& Jurnal Akuntansi

e-ISSN : 2548-9224|p-ISSN : 2548-7507

Volume 6 Nomor 1, Januari 2022

DOI : https://doi.org/10.33395/owner.v6i1.647

\begin{tabular}{|l|l|l|l|}
\hline Cross-section Chi-square & 73.481319 & 48 & 0.0104 \\
\hline
\end{tabular}

Sumber Tabel: Pengolahan Data Eviews9

Berdasarkan hasil dari Uji Chow pada tabel 8, diketahui nilai probabilitas adalah 0.0104. Karena nilai probabilitas $<0.05$, maka $\mathrm{H} 0$ ditolak dan $\mathrm{H} 1$ diterima, dengan kata lain maka model estimasi yang digunakan adalah Fixed Effect Model (FEM)

\section{Uji Hausman}

Tabel 8. Uji Hausman

\begin{tabular}{|c|c|c|c|}
\hline \multicolumn{3}{|c|}{ Correlated Random Effects - Hausman Test } & \\
\hline \multicolumn{3}{|c|}{ Equation: Untitled } & \\
\hline \multicolumn{3}{|c|}{ Test cross-section random effects } & \\
\hline Test Summary & Chi-Sq. Statistic & Chi-Sq. d.f. & Prob. \\
\hline Cross-section random & 2.567246 & 3 & 0.4633 \\
\hline
\end{tabular}

Sumber Tabel: Pengolahan Data Eviews9

Berdasarkan hasil uji Hausman pada tabel 9, diketahui nilai probabilitas adalah 0.4633. Karena nilai probabilitas > 0.05 maka H0 diterima dan H1 ditolak atau Random Effect Model (REM) lebih baik dari pada Fixed Effect Model (FEM)

Uji Hipotesis

Berdasarkan pengujian yang telah dilakukan menunjukkan bahwa model yang terpilih yaitu Model Random Effect.

Tabel 9. Uji Hipotesis

\begin{tabular}{|c|c|c|c|}
\hline \multicolumn{4}{|l|}{ Dependent Variable: ROA } \\
\hline \multicolumn{4}{|c|}{ Method: Panel EGLS (Cross-section random effects) } \\
\hline \multicolumn{4}{|c|}{\begin{tabular}{|l|l|} 
Sample: 20182020 & \\
\end{tabular}} \\
\hline \multicolumn{4}{|l|}{ Periods included: 3} \\
\hline \multicolumn{4}{|l|}{ Cross-sections included: 49} \\
\hline \multicolumn{4}{|c|}{ Total panel (balanced) observations: 147} \\
\hline \multicolumn{4}{|c|}{ Swamy and Arora estimator of component variances } \\
\hline \begin{tabular}{|l|l} 
Variable & Coefficient \\
\end{tabular} & Std. Error & t-Statistic & Prob. \\
\hline-0.019065 & 0.011169 & -1.706919 & 0.0900 \\
\hline 0.009687 & 0.007491 & 1.293129 & 0.1981 \\
\hline-0.008526 & 0.004034 & -2.113624 & 0.0363 \\
\hline 0.333635 & 0.065635 & 5.083219 & 0.0000 \\
\hline R-squared & \multicolumn{2}{|c|}{ Mean dependent var } & 0.014580 \\
\hline \begin{tabular}{|ll|l}
$\begin{array}{l}\text { Adjusted } \\
\text { squared }\end{array}$ & $\mathrm{R}-$ & \\
sq.209513
\end{tabular} & \multicolumn{2}{|c|}{ S.D. dependent var } & 0.059395 \\
\hline S.E.of regression 0.052808 & \multicolumn{2}{|c|}{ Sum squared resid } & 0.398779 \\
\hline \begin{tabular}{|l|l|} 
F-statistic & 13.89874 \\
\end{tabular} & \multicolumn{2}{|c|}{ Durbin-Watson stat } & 1.235860 \\
\hline \begin{tabular}{|l|l|} 
Prob(F-statistic) & 0.000000 \\
\end{tabular} & & & \\
\hline
\end{tabular}

Sumber Tabel: Hasil Pengolahan Data Eviews9

\section{Uji Signifikansi Pengaruh (Uji F)}

Berdasarkan Tabel 9, nilai probabilitas dari uji F adalah (Prob(F-Statistic)) adalah 0.000000. Karena nilai probabilitas, yakini 0.000000 lebih kecil dari tingkat signifikansi, yaitu 0,05 Maka dapat disimpulkan secara serempak, Sales Growth (SG), Debt to Equity Ratio (DER), dan Total Assets Turnover (TATO) berpengaruh signifikansi terhadap Return on Assets (ROA) Perusahaan property dan real estate yang terdaftar di Bursa Efek Indonesia (BEI).

\section{Uji Signifikansi Pengaruh Parsial (Uji t)} berikut:

Hasil uji signifikansi pengaruh secara parsial (uji-t) berdasarkan tabel 10 adalah sebagai 
Nilai koefisien dari variabel bebas Sales Growth (SG) adalah 0.009687, yakni bernilai positif. Nilai tersebut dapat diinterpretasikan bahwa nilai SG berpengaruh positif terhadap Return on Assets (ROA), dengan asumsi variabel dianggap konstan. Nilai profitabilitas dari variabel Sales Growth (SG) adalah 0.1981, yakni > 0.05, maka variabel Sales Growth (SG) berpengaruh positif dan tidak signifikan terhadap Return on Assets (ROA )pada tingkat signifikansi 5\%.

Nilai koefisien dari variabel bebas Debt to Equity Ratio (DER) adalah -0.008526, yakni bernilai negatif. Nilai tersebut dapat diinterpretasikan bahwa nilai DER berpengaruh negatif terhadap Return on Assets (ROA), dengan asumsi variabel dianggap konstan. Nilai probabilitas dari variabel Debt to Equity Ratio (DER) adalah 0.0363, yakni <0.05, maka variabel Debt to Equity Ratio (DER) berpengaruh negatif dan signifikan Return on Assets (ROA) pada tingkat signifikansi $5 \%$.

Nilai koefisien dari variabel bebas Total Assets Turnover (TATO) adalah 0.333635 , yakni bernilai positif. Nilai tersebut dapat diinterpretasikan bahwan nilai TATO berpengaruh positif terhadap Return on Assets (ROA), dengan asumsi variabel dianggap konstan. Nilai probabilitas dari variabel Total Assets Turnover (TATO) adalah 0.000, yakni <0.05, maka variabel Total Assets Turnover (TATO) berpengaruh positif dan signifikan terhadap Return on Assets (ROA) pada tingkat signifikansi 5\%.

\section{Analisis Koefisien Determinasi (R2)}

Berdasarkan Tabel 10, diketahui bahwa nilai Adjusted R-Squared sebesar 0.225756, nilai tersebut menginterpretasikan bahwa Sales Growth (SG), Debt to Equity Ratio (DER), Total Assets Turnover (TATO) mampu memengaruhi/ menjelaskan tingkat Return on Assets (ROA) secara bersama-sama sebesar $22.58 \%$ sehingga sebesar $77.42 \%$ dipengaruhi oleh faktor-faktor lain yang tidak disebutkan dalam penelitian ini. Dengan demikian dapat disimpulkan bahwa Sales Growth (SG), Total Assets Turnover (DER), Total Assets Turnover (TATO) tidak mampu menjelaskan perubahan variabel Return on Assets (ROA).

\section{PEMBAHASAN \\ Pengaruh Sales Growth (SG) terhadap Return on Assets (ROA)}

Hasil yang diperoleh menunjukkan nilai koefisien dari variabel bebas Sales Growth (SG) terhadap Return on Assets (ROA) adalah 0.009687, yakni bernilai positif. Nilai tersebut dapat diinterpretasikan bahwan nilai SG berpengaruh positif terhadap Return on Assets(ROA), dengan asumsi variabel dianggap konstan. Nilai probabilitas dari variabel Sales Growth (SG) adalah 0.1981, yakni >0.05, maka variabel Sales Growth (SG) berpengaruh positif dan tidak signifikan terhadap Return on Assets (ROA). Adanya pengaruh tidak signifikan ini menunjukkan bahwa Sales Growth (SG) tidak menjadi penentuan dalam pencapaian laba perusahaan. Penelitian yang dilakukan (Putra \& Badjra, 2015) menyatakan bahwa penjualan perusahaan bisa menutupi biaya sehingga hal ini akan menaikan keuntungan, tetapi pada perusahaan property dan real estate pertumbuhan penjualan disertai dengan meningkatnya biaya bahan baku, gaji, dan lainnya sehingga naiknya nilai profitabilitas perusahaan yang diinginkan tidak bisa tercapai menutupi biaya yang dikeluarkan oleh perusahaan. Hasil penelitian ini sejalan dengan penelitian yang dilakukan oleh (Wulandari \& Gultom, 2018) tidak berpengaruh terhadap Return on Assets (ROA) pada perusahaan makanan dan minuman sedangkan penelitian ini pada hasil pengujian terdapat hasil yang berbeda dilakukan oleh (Arifin, Sarita, Montundu, \& Madi, 2019), yang diketahui hasil penelitian menunjukkan adanya pengaruh positif dan signifikan.

\section{Pengaruh Debt to Equity Ratio (DER) terhadap Return on Asset (ROA)}

Hasil yang diperoleh menunjukkan nilai koefisien variabel bebas Debt to Equity Ratio (DER) terhadap Return on Assets (ROA) adalah -0.008526, yakni bernilai negatif. Nilai tersebut dapat diinterpretasikan bahwa nilai DER berpengaruh negatif terhadap Return on Assets (ROA). Nilai probabilitas dari variabel Debt to Equity Ratio (DER) adalah 0.0363, yakni lebih kecil dari 0.05, maka variabel Debt to Equity Ratio (DER), berpengaruh dan negatif dan signifikan terhadap Return on Assets (ROA). Hasil yang negatif menunjukkan bahwa adanya peningkatan Debt to Equity Ratio (DER) yang mengakibatkan laba yang diukur mengalami penurunan disebabkan 
beban bunga yang dibayarkan oleh perusahaan.Hasil yang diperoleh sejalan dengan penelitian yang dilakukan (Jenni, et al., 2019) pada pengujian hipotesis bahwa Debt to Equity Ratio (DER) berpengaruh negatif dan signifikan terhadap Return on Assets (ROA) selain itu penelitian yang dilakukan oleh (Mahardhika \& Marbun,, 2016) yang menunjukkan hasil berpengaruh negatif dan signifikan pada PT Bank Mandiri tahun 2008-2015.

\section{Pengaruh Total Assets Turnover (TATO) terhadap Return On Assets (ROA)}

Hasil yang diperoleh menunjukkan nilai koefisien variabel bebas Total Assets Turnover (TATO) terhadap Return on Assets (ROA) adalah 0.333635, yakni bernilai positif. Nilai tersebut dapat diinterpretasikan bahwa nilai TATO berpengaruh positif terhadap Return on Assets (ROA), dengan asumsi variabel dianggap konstan. Nilai probabilitas dari variabel Total Assets Turnover (TATO) adalah 0.000 , yakni $<0.05$ yang artinya berpengaruh positif dan signifikan. Total Assets Turnover (TATO) adalah rasio menghitung efektivitas dalam penggunaan aktiva dalam menghasilkan keuntungan yang diperoleh perusahaan. Semakin tinggi Total Assets Turnover (TATO) maka akan meningkatkan Return on Assets (ROA). Hasil ini sejalan dengan penelitian yang dilakukan (Tyas, 2018) dan (Arsyanti, Tripuspitorini, \& Djatnika, 2020) berpengaruh positif dan signifikan

\section{KESIMPULAN}

Berdasarkan hasil penelitian dan pembahasan yang telah dikemukakan sebelumnya maka kesimpulan penelitian ini adalah sebagai berikut:

1. Sales Growth, Debt to Equity Ratio (DER) dan Total Assets Turnover (TATO) secara serempak berpengaruh signifikan terhadap Return on Assets (ROA) perusahaan sub sektor property dan real estate di Bursa Efek Indonesia (BEI) periode 2018-2020.

2. Sales Growth (SG) berpengaruh positif dan tidak signifikan terhadap Return on Assets (ROA) perusahaan sub sektor property dan real estate di Bursa Efek Indonesia (BEI) periode 20182020.

3. Debt to Equity Ratio (DER) berpengaruh negatif dan signifikan terhadap Return on Assets (ROA) perusahaan sub sektor property dan real estate di Bursa Efek Indonesia (BEI) periode 20182020.

4. Total Assets Turnover (TATO) berpengaruh positif dan signifikan terhadap Return on Assets (ROA) perusahaan sub sektor property dan real estate di Bursa Efek Indonesia (BEI) periode 2018-2020.

\section{REFERENSI}

Anggarsari, L., \& Aji, T. S. (2018). PENGARUH UKURAN PERUSAHAAN, LEVERAGE, LIKUIDITAS, PERPUTARAN MODAL KERJA DAN PERTUMBUHAN PENJUALAN TERHADAP PROFITABILITAS(SEKTOR INDUSTRI BARANG DAN KONSUMSI YANG TERDAFTAR DI BURSA EFEK INDONESIA PERIODE 2013 2016). Jurnal Ilmu Manajemen, 6(4), 542-549.

Arifin, D. S., Sarita, B., Montundu, Y., \& Madi, R. A. (2019). PENGARUH LIKUIDITAS, LEVERAGE, UKURAN PERUSAHAAN DAN PERTUMBUHAN PENJUALAN TERHADAP PROFITABILITAS Tahun 2013-2017). Jurnal Manajemen \& Kewirausahaan, 11(2), 38-52.

Arsyanti, H., Tripuspitorini, F. A., \& Djatnika, D. (2020). Pengaruh Total Assets Turnover dan Current Ratio terhadap Return on Assets pada Perusahaan Properti dan Real Estate di BEI (2014-2018). Indonesian Journal of Economics and Management, 1(1), 150-162.

Damayanti, E., \& Chaerudin. (2021). THE ROLE OF CURRENT RATIO (CR), DEBT TO EQUITY RATIO (DER), AND TOTAL ASSET TURNOVER (TATO) ON RETURN ON ASSET (ROA) IN MULTI-INDUSTRIAL SECTOR MANUFACTURING COMPANIES THAT REGISTERED TO THE INDONESIA STOCK EXCHANGE FOR 2015-2019. 2(6), 915-924. doi:https://doi.org/10.31933/dijms.v2i6

Darminto , A. A., \& Fuadati, S. R. (2020). PENGARUH CR, DER, TATO TERHADAP ROA PADA PERUSAHAAN ROKOK DI BEI. Jurnal Ilmu dan Riset Manajemen, 9(4), 1-13. 
Fadilah, N., Ghani , E., \& Amaniyah , E. (2017). PENGARUH QUICK RATIO, INVENTORY TURNOVER DAN DEBT TO EQUITY RATIO TERHADAP RENTABILITAS PADA PERUSAHAAN KABEL YANG TERDAFTAR DI BURSA EFEK INDONESIA. Kompetensi, 11(1), 89-108.

Ferica, Nauli, A., Couwinata, C., \& Sukhenny. (2020). PENGARUH LIKUIDITAS, TOTAL ASSET TURNOVER, DEBT TO EQUITY RATIO DAN PERPUTARAN PERSEDIAAN TERHADAP PROFITABILITAS PERUSAHAAN MANUFAKTUR. COSTING:Journal of Economic, Business and Accounting, 3(2), 336-344.

Hantono. (2018). Konsep Analisa Laporan Keuangan Dengan Pendekatan Rasio Dan SPSS. Yogyakarta: Deepublish.

Harahap, S. S. (2015). Analisis Kritis Atas Laporan Keuangan. Jakarta: Rajawali Press.

Hatami, M. R., \& Dr. Hendratno SE., Ak., MM.,. (2020). PENGARUH CURRENT RATIO, DEBT TO EQUITY RATIO, DAN TOTAL ASSET TURN OVER TERHADAP RETURN ON ASSET (Studi pada Perusahaan Farmasi yang terdaftar di Bursa Efek Indonesia tahun 2012-2017). e-Proceeding of Management :, 7(1), 696-701.

Ibrahim, F. T., \& Widyarti, E. T. (2015). ANALISIS PENGARUH LEVERAGE, LIKUIDITAS, PERPUTARAN MODAL KERJA, DAN PERTUMBUHAN PENJUALAN TERHADAP PROFITABILITAS PERUSAHAAN (Studi pada Perusahaan Manufaktur Sektor Industri Barang Konsumsi yang Terdaftar di BEI pada Tahun 2009-2013). DIPONEGORO JOURNAL OF MANAGEMENT, 4(3), 1-9.

Imam, N. P., \& Isynuwardana, D. (2019). PENGARUH LIKUDITAS, LEVERAGE DAN SALES GROWTH TERHADAP PROFITABILITAS PERUSAHAAN SEKTOR PROPERTI DAN REAL ESTATE YANG TERDAFTAR DI BEI PERIODE 2014-2017. eProceeding of Management, 6(2), 3411-3417.

Jenni, Wanny, T., Yeni, L., Merrissa, Erlin, \& Nasution, I. A. (2019). Pengaruh TATO, DER dan Current Ratio terhadap ROA pada Perusahaan Property dan Real Estate. OWNER RISET \& JURNAL AKUNTANSI, 3(2), 139-152. doi:https://doi.org/10.33395/owner.v3i2.127

Laela, R. H., \& Hendratno. (2019). APENGARUH CURRENT RATIO, DEBT TO EQUITY RATIO DAN TOTAL ASSET TURNOVER TERHADAP RETURN ON ASSET. JASa ( Jurnal Akuntansi, Audit dan Sistem Informasi Akuntansi ), 3(1), 120-131.

Mahardhika, P., \& M. D. (2016). Pengaruh Current Ratio Dan Debt To Equity Ratio Terhadap Return On Assets. Widyakala, 3, 23-28.

Mappanyuki, R., \& Sari, M. (2017). THE EFFECT OF SALES GROWTH RATIO, INVENTORY TURN OVER RATIO, GROWTH OPPORTUNITY TO COMPANY'S PROFITABILITY (SURVEY IN INDONESIA'S STOCKS EXCHANGE). International Journal of Management and Applied Science, 3(3), 139-147.

Meidiyustiani, R. (2016). PENGARUH MODAL KERJA, UKURAN PERUSAHAAN, PERTUMBUHAN ENJUALAN DAN LIKUIDITAS TERHADAP PROFITABILITAS PADA PERUSAHAAN MANUFAKTUR SEKTOR INDUSTRI BARANG KONSUMSI YANG TERDAFTAR DI BURSA EFEK INDONESIA (BEI) PERIODE TAHUN 2010 - 2014. Jurnal Akuntansi dan Keuangan, 5(2), 41-59.

Putra, A. Y., \& Badjra, I. B. (2015). PENGARUH PERTUMBUHAN PENJUALAN DAN UKURAN PERUSAHAAN TERHADAP PROFITABILITAS. E-Jurnal Manajemen Unad, 4(7), 2052-2067.

Rambe, I., Arif, M., \& Tupti, Z. (2021). Pengaruh Current Ratio, Debt Equity Ratio, dan Total Asset Turnover, terhadap Return On Asset yang Terdaftar di Bursa Efek Indonesia. Jurnal Riset Akuntansi dan Bisnis, 21(2), 147-161. doi:https://dx.doi.org/10.30596\%2Fjrab.v21i2.7898

Sanjaya, I., Sudirman, I., \& Dewi, M. (2015). PENGARUH LIKUIDITAS DAN AKTIVITAS TERHADAP PROFITABILITAS PADA PT PLN (PERSERO). E-Journal Manajemen Unud, 4(8), 2350-2359.

Saragih, B. L., \& Suzan, L. (2021). PENGARUH PERPUTARAN KAS, PERPUTARAN PERSEDIAAN DAN PERTUMBUHAN PENJUALAN TERHADAP PROFITABILITAS. 9thApplied Business and Engineering Conference, 1-19. 
Sari, W. I., \& Aulia, D. E. (2021). PENGARUH TOTAL ASSET TURN OVER DEBT TO ASSET RATIO DAN SALES GROWTH TERHADAP RETURN ON ASSET PT ULTRAJAYA MILK INDUSTRI CO TBK PERIODE 2010-2019. Neraca Peradaban, 1(2), 214-225.

Setiawan, A., \& Cahyono, K. E. (2019). PENGARUH RASIO KEUANGAN DER, CR, TATO TERHADAP ROA PERUSAHAAN MAKANAN DAN MINUMAN. Jurnal EKSEKUTIF, 16(2), 379-398.

Sudana, I. M. (2015). Manajemen Keuangan Teori dan Praktik. Surabaya: Airlangga University Press.

Susetyo, A. (2017). ANALISIS PENGARUH CURRENT RATIO, DEBT TO EQUITY RATIO DAN TOTAL ASSET TURNOVER TERHADAP RETURN ON ASSET PADA PERUSAHAAN YANG TERCATAT DI JAKARTA ISLAMIC INDEX. Jurnal Ilmiah Akuntansi dan Keuangan, 6(1), 130-142.

Tyas, E. P. (2018). PENGARUH CURRENT RATIO, TOTAL ASSET TURN OVER, DAN NET PROFIT MARGIN TERHADAP RETURN ON ASSET PADA PERUSAHAAN SUBSEKTOR MAKANAN DAN MINUMAN YANG TERDAFTAR DI BEI PADA TAHUN 2012-2016. Jurnal Ekobis Dewantara, 1(1), 77-84.

Widodo, A. (2018). ANALISIS PENGARUH CURRENT RATIO (CR), TOTAL ASSET TURNOVER (TATO), DEBT TO ASSET RATIO (DAR) TERHADAP RETURN ON ASSET (ROA), SERTA DAMPAKNYA TERHADAP NILAI PERUSAHAAN (Studi Perusahaan Jasa Penunjang MigasPada Bursa Efek Indonesia Periode Tahun 2010-2014. Jurnal Ilmiah Manajemen Forkamma, 1(2), 87-112.

Wikardi, L. D., \& Natalia , W. T. (2017). Pengaruh Debt to Equity Ratio, Firm Size, Inventory Turnover, Assets Turnover dan Pertumbuhan Penjualan Terhadap Profitabilitas (Studi Kasus Pada Industri Makanan dan Minuman yang Terdaftar di BEI Periode 2011-2015). JURNAL ONLINE INSAN AKUNTAN, 2(1), 99 - 118.

Wulandari, P., \& Gultom, R. (2018). PENGARUH LIKUIDITAS, AKTIVITAS DAN PERTUMBUHAN PENJUALAN TERHADAP PROFITABILITAS PADA PERUSAHAAN INDUSTRI MAKANAN DAN MINUMAN YANG TERDAFTAR DI BURSA EFEK INDONESIA TAHUN 2014-2017. Jurnal Ilmiah Methonomi, 4(1), 101110.

Zaman, M. B. (2021). Influence of Debt To Total Asset Ratio (DAR) Current Ratio (CR) and Total Asset Turnover (TATO) on Return On Asset (ROA) and Its Impact on Stock Prices on Mining Companies on the Indonesia Stock Exchange in 2008-2017. JOURNAL OF INDUSTRIAL ENGINEERING \& MANAGEMENT RESEARCH, 2(1), 114-132. doi:https://doi.org/10.7777/jiemar 